\title{
Comparison of Clinical Features and Treatment Outcomes of Young and Older Adult Patients with Primary Immune Thrombocytopenia
}

\author{
Primer İmmün Trombositopenili Genç ve Yaşl Erişkin Hastalarm Klinik Özelliklerinin ve Tedavi Sonuçlarının \\ Karşılaştııılması
}

\section{Bilal Aygun, Didar Yanardag Acik}

Department of Hematology, University of Health Sciences Adana City Training and Research Hospital, Adana, Turkey

\section{Correspondence:}

Didar YANARDAĞ AÇK

Department of Hematology,

University of Health Sciences Adana

City Training and Research Hospital,

Adana, Turkey,

e-mail: didaryanardag@gmail.com

\section{Abstract}

In this study, we aimed to investigate the discrepancies regarding the clinical characteristics and the treatment outcomes between immune thrombocytopenic purpura patients $\leq 60 \mathrm{y}$ and $>60 \mathrm{y}$, which is the cut-off age for the definition of old age by the WHO We retrospectively analyzed the data of 67 immune thrombocytopenic purpura patients diagnosed and treated in the Hematology clinic between December 2014 and February 2019. The median age of the patients was 44 years (range, 17-86); 48 (71.6\%) patients were female and $19(28.4 \%)$ were male. There were $50(74.6 \%)$ patients aged $\leq 60 \mathrm{y}$ and $17(25.4 \%)$ patients $>60 \mathrm{y}$. When two groups were compared with respect to treatment features, they were similar in responding to the therapies, the loss of response to therapies and in duration of response to the therapies $(p>0.05)$. When the cutoff point for age was 50 and 65 years again the groups were similar in terms of disease and treatment characteristics $(\mathrm{p}>0.05)$. Despite the clinical complexicity and heterogeneity of older adults, the treatment outcomes of olderimmune thrombocytopenic purpura patients seem to be similar to the young ones.

Keywords: ITP, fragility, treatment outcomes, older adults

\section{Özet}

Bu çalışmada, DSÖ'nün yaşlılık tanımı için kesme yaşı olan 60 yaş ve üstü immun trombositopenik purpura hastaları arasında klinik özellikler ve tedavi sonuçları ile ilgili farklılıkları araştırmayı amaçladık. Yöntem: Aralık 2014 ile Şubat 2019 arasında Hematoloji kliniğinde teshis ve tedavi edilen 67 immun trombositopenik purpura hastasının verilerini geriye dönük olarak analiz ettik. Hastaların ortanca yaşı 44 (aralık, 17-86); hastaların 48'i $(\% 71,6)$ kadın, 19'u (\%28,4) erkekti. $\leq 60$ yaşında 50 (\%74.6) hasta ve > 60 yaşında 17 (\%25.4) hasta vardı. Tedavi özellikleri açısından iki grup karşılaştırıldığında, tedavilere yanıt verme, tedavilere yanıt kaybı ve tedavilere yanıt süresi açısından benzerdi ( $p>0.05)$. Yaș için kesme noktası 50 ve 65 olduğunda yine gruplar hastalık ve tedavi özellikleri açısından benzerdi ( $\mathrm{p}>0.05)$. Yaşlı yetişkinlerin klinik karmaşıklığına ve heterojenliğine rağmen, yaşlı immun trombositopenik purpura hastalarının tedavi sonuçları gençlere benzer görünmektedir.

Anahtar Kelimeler: ITP, frajilite, tedavi sonuçları, yaşlı erişkinler 


\section{Introduction}

Immune thrombocytopenic purpura (ITP) is one of the acquired autoimmune diseases characterized by sole thrombocytopenia as a result of the peripheral destruction and impaired production of platelets.1-4 While minority of the patients have a secondary cause such as hepatitis $\mathrm{C}$, human immunodeficiency virus, systemic lupus erythematosus, antiphosholipid syndrome, immune deficiency; a specific underlying stimulus could not be demonstrated in most of the ITP patients [3,4].3,4 The standard first line therapy is corticosteroids (CSs) for ITP patients who require treatment [4-6].4-6 Although the response rates to $\mathrm{CSs}$ are convincing at first, the achievement of a durable response is not feasible in most of the ITP patients when CS treatment is interrupted.5 In the steroid refractory ITP patients splenectomy, thrombopoietin receptor agonists, rituximab and other immunsupressive drugs are the treatment of choices. 6

According to the World Health Organization (WHO), the world's population is getting older and it is estimated that the world's population over 60 years will increase from $12 \%$ to $22 \%$ between 2015 and 2050.7 Comorbidities emerging with increased age and altered drug metbolism are important issues to be considered in the management of diseases, in older people.8,9 From this point of view, there is insufficient data comparing the clinical parameters and treatment responses of young and old ITP patients. In this study, we aimed to investigate the discrepancies regarding the clinical characteristics and the treatment outcomes between ITP patients $\leq 60 \mathrm{y}$ and $>60 \mathrm{y}$, which is the cut-off age for the definition of old age by the WHO.7-10

\section{Material and Methods}

We retrospectively analyzed the data of 67 primary ITP patients diagnosed and treated in the Hematology clinic between December 2014 and February 2019. The data including age, gender, bleeding history, complete blood cell count at the time of diagnosis, history of patients and treatment characteristics were noted for each patient. The diagnosis of ITP and treatment criteria were defined according to The American Society of Hematology practice guidelines. 4 We started

treatment for patients with platelet count below 30x109/L or patients with bleeding. Response to treatment was evaluated with respect to the recommendations of the international working group.11 Complete response (CR) was described as a platelet count greater than $100 \times 109 / \mathrm{L}$, response (R) was described as a platelet count greater than $30 \times 109 / \mathrm{L}$ and no response (NR) was described as a platelet count less than 30x109/L. In patients responding to treatment, loss of response (LOR) was defined as a platelet count less than $30 \times 109 / \mathrm{L}$ or a less than 2-fold decrease in the platelet count from baseline or the presence of bleeding. Two low platelet count was needed to diagnose loss of response.

The study protocol was approved by the local ethical committee.

\section{Statistical Analysis}

Statistical evaluation was made by using SPSS 24 software. Data were described as numbers and percentage or median and range, when appropriate. x2, Fisher's exact test was used for evaluating categorical values and Mann-Whitney U test for continuous values in patient groups. All p-values were 2-sided with statistical significance at 0.05 alpha levels.

\section{Results}

The patients and their treatment characteristics are presented in table 1 and 2 . The median age of the patients was 44 years (range, 17-86); $48(71.6 \%)$ patients were female and 19 (28.4\%) were male. The bleeding history at the time of diagosis was present in $36(53.7 \%)$ patients. The median white blood cell count was $8200 / \mathrm{mm} 3$ (2200$16850 / \mathrm{mm} 3)$, hemoglobin level was $12.7 \mathrm{~g} / \mathrm{dl}$ $(5.7-17.3 \mathrm{~g} / \mathrm{dl})$, platelet count was $15500 / \mathrm{mm} 3$ $(1000-43000 / \mathrm{mm} 3)$. Twenty $(29.9 \%)$ patients had at least one comorbidity and $16(23.9 \%)$ patients were on at least one medication (table1). 
Table 1. Patient Characteristics

\begin{tabular}{|c|c|}
\hline Characteristic & $\mathrm{N}=67$ \\
\hline $\begin{array}{l}\text { Gender, } \mathbf{n},(\mathbf{\%}) \\
\text { Female } \\
\text { Male } \\
\text { Age, years, median, (range) }\end{array}$ & $\begin{array}{l}48(71.6 \%) \\
19(28.4 \%) \\
44(17-86)\end{array}$ \\
\hline $\begin{array}{l}\text { Bleeding, } \mathbf{n}, \mathbf{( \% )} \\
\text { Present } \\
\text { Absent } \\
\text { WBC, } / 10^{3} / \mathrm{mm}^{3} \text {, median (range) } \\
\mathrm{Hgb}, / \mathrm{g} / \mathrm{dl}, \text { median (range) } \\
\mathrm{Plt}, / 10^{3} / \mathrm{mm}^{3}, \text { median (range) }\end{array}$ & $\begin{array}{l}36(53.7 \%) \\
31(46.3 \%) \\
8200(2200-16850) \\
12.7(5.7-17.3) \\
15500(1000-43000)\end{array}$ \\
\hline $\begin{array}{l}\text { Comorbidity, n, (\%) } \\
\text { Present } \\
\text { Absent }\end{array}$ & $\begin{array}{l}20(29.9 \%) \\
47(70.1 \%)\end{array}$ \\
\hline $\begin{array}{l}\text { Other medication } \\
\text { Present } \\
\text { Absent }\end{array}$ & $\begin{array}{l}16(23.9 \%) \\
51(76.1 \%)\end{array}$ \\
\hline
\end{tabular}

hgb: hemoglobin; plt:platelet; WBC: white blood cell count

Regarding the response to CS treatment, 38 (56.7\%) patients had CR, $20(29.9 \%)$ patients had $\mathrm{R}$ and 9 (13.4\%) patients had NR. And loss of response developed in $20(34.5 \%)$ of these patients during follow-up. The response duration to CS therapy was median 6 (range, $1-53)$ months. Twenty (29.8\%) patients were applied IVIG and the response to IVIG therapy was $\mathrm{CR}$ in 9 (45\%) patients, $\mathrm{R}$ in 10 $(50 \%)$ patients and NR in $1(5 \%)$ patient. Fifteen (22.3\%) patients underwent splenectomy and the response to splenectomy was $\mathrm{CR}$ in $8(53.3 \%)$ patients, $\mathrm{R}$ in $5(33.3 \%)$ patients and NR in $2(13.4 \%)$ patients. The loss of response to splenectomy was observed in $10(66.7 \%)$ patients. Twenty-four (35.8\%) patients were applied eltrombopag and the response to eltrombopag therapy was $\mathrm{CR}$ in $13(54.1 \%)$ patients, $\mathrm{R}$ in $9(37.5 \%)$ and NR in $2(8.4 \%)$ patients. The loss of response to eltrombopag therpy was seen in $3(12.5 \%)$ patients. The response duration to eltrombopag therapy was median 8.5 months (range, 1-51) (table 2).

Table 2. Treatment Characteristics

\begin{tabular}{|c|c|}
\hline \multicolumn{2}{|l|}{ Characteristics } \\
\hline \multicolumn{2}{|l|}{ Response to corticosteroid therapy, n, (\%) } \\
\hline $\mathrm{CR}$ & $38(56.7 \%)$ \\
\hline Response & $20(29.9 \%)$ \\
\hline No response & $9(13.4 \%)$ \\
\hline \multicolumn{2}{|l|}{ Loss of response to corticosteroid, $n,(\%)$} \\
\hline Present & $20(34.5 \%)$ \\
\hline Absent & $38(65.5 \%)$ \\
\hline $\begin{array}{l}\text { Response duration to corticosteroid therapy, months, } \\
\text { median (range) }\end{array}$ & $6(1-53)$ \\
\hline The number of patients who were applied IVIG, n, (\%) & $20(29.8 \%)$ \\
\hline \multicolumn{2}{|l|}{ Response to IVIG therapy, n, (\%) } \\
\hline $\mathrm{CR}$ & $9(45 \%)$ \\
\hline Response & $10(50 \%)$ \\
\hline No response & $1(5 \%)$ \\
\hline The number of patients who underwent splenectomy, n (\%) & $15(22.3 \%)$ \\
\hline \multicolumn{2}{|l|}{ Response to splenectomy, $\mathbf{n},(\%)$} \\
\hline $\mathrm{CR}$ & $8(53.3 \%)$ \\
\hline Response & $5(33.3 \%)$ \\
\hline No response & $2(13.4 \%)$ \\
\hline Loss of response to splenectomy & \\
\hline
\end{tabular}




\begin{tabular}{ll}
\hline Yes & $10(66.7 \%)$ \\
No & $5(33.3 \%)$ \\
The number of patients who were applied eltrombopag, $\mathrm{n}$ & $24(35.8 \%)$ \\
$(\%)$ & \\
Response to eltrombopag therapy, n, (\%) & $13(54.1 \%)$ \\
CR & $9(37.5 \%)$ \\
Response & $2(8.4 \%)$ \\
No response & \\
Loss of response to eltrombopag, n, (\%) & $3(12.5 \%)$ \\
Present & $19(79.1 \%)$ \\
Absent & $2(8.4 \%)$ \\
Missing & $8.5(1-51)$ \\
\hline Response duration to eltrombopag, months, median (range) & \\
\hline CR: complete response &
\end{tabular}

There were $50(74.6 \%)$ patients aged $\leq 60 \mathrm{y}$ and $17(25.4 \%)$ patients $>60 \mathrm{y}$. Two groups were comparable in terms of gender, bleeding history, WBC count, Hb level, PLT count ( $\mathrm{p}>$
$0.05)$. However, history of comorbidity and use of another medication were more prominent in older patients $(\mathrm{p}<0.05)($ table 3$)$.

Table 3. Comparison of clinical features of ITP patients with $\leq 60$ years and $>60$ years

\begin{tabular}{|c|c|c|c|}
\hline Characteristic & $\begin{array}{c}\leq 60 \\
\mathrm{~N}=50\end{array}$ & $\begin{array}{c}>60 \\
N=17\end{array}$ & $\mathrm{P}$ value \\
\hline $\begin{array}{l}\text { Gender, } \mathbf{n},(\%) \\
\text { Female } \\
\text { Male }\end{array}$ & $\begin{array}{l}38(76 \%) \\
12(24 \%)\end{array}$ & $\begin{array}{c}10(58.8 \%) \\
7(41.2 \%)\end{array}$ & 0.217 \\
\hline $\begin{array}{l}\text { Bleeding, } \mathbf{n},(\%) \\
\text { Present } \\
\text { Absent }\end{array}$ & $\begin{array}{l}24(48 \%) \\
26(52 \%)\end{array}$ & $\begin{array}{c}12(70.6 \%) \\
5(29.4 \%)\end{array}$ & 0.159 \\
\hline $\begin{array}{l}\mathrm{WBC}, / 10^{3} / \mathrm{mm}^{3}, \text { median (range) } \\
\mathrm{Hgb}, / \mathrm{g} / \mathrm{dl} \text {, median (range) } \\
\mathrm{Plt}, / 10^{3} / \mathrm{mm}^{3} \text {, median (range) }\end{array}$ & $\begin{array}{c}8420(2200-16850) \\
12.85(5.7-17.3) \\
16500(1000-43000)\end{array}$ & $\begin{array}{c}7400(4480-14300) \\
12.1(7.5-16.7) \\
11500(4000-33000)\end{array}$ & $\begin{array}{l}0.293 \\
0.141 \\
0.355\end{array}$ \\
\hline $\begin{array}{l}\text { Comorbidity, } \mathbf{n},(\%) \\
\text { Present } \\
\text { Absent }\end{array}$ & $\begin{array}{l}11(22 \%) \\
39(78 \%)\end{array}$ & $\begin{array}{l}9(52.9 \%) \\
8(47.1 \%)\end{array}$ & 0.029 \\
\hline $\begin{array}{l}\text { Other medication } \\
\text { Present } \\
\text { Absent }\end{array}$ & $\begin{array}{c}8(16 \%) \\
42(84 \%)\end{array}$ & $\begin{array}{l}8(47.1 \%) \\
9(52.9 \%)\end{array}$ & 0.018 \\
\hline
\end{tabular}

hgb: hemoglobin; plt:platelet; WBC: white blood cell count

When two groups were compared with respect to treatment features, they were similar in responding to the therapies, the loss of response to therapies and in duration of response to the therapies $(p>0.05)$ (table 4$)$.
When the cutoff point for age was 50 and 65 years again the groups were similar in terms of disease and treatment caharacteristics $(p>00.5)$.

Table 4. Comparison of treatment outcomes of ITP patients with $\leq 60$ years and $>60$ years

\begin{tabular}{llll}
\hline Characteristics & $\leq 60$ & $>60$ & P value \\
& $\mathrm{N}=50$ & & \\
Response to corticosteroid therapy, $\mathbf{n}, \mathbf{( \% )}$ & & $11(64.8 \%)$ & 0.429 \\
CR & $27(54 \%)$ & $3(17.6 \%)$ & \\
Response & $17(34 \%)$ & $3(17.6 \%)$ & \\
No response & $6(12 \%)$ & $5(35.7 \%)$ & 1.000 \\
Loss of response to corticosteroid, n, (\%) & $15(34.1 \%)$ & $9(64.3 \%)$ & \\
Present & $29(65.9 \%)$ & \\
Absent & &
\end{tabular}




\begin{tabular}{|c|c|c|c|}
\hline $\begin{array}{l}\text { Response duration to corticosteroid therapy, months, } \\
\text { median (range) }\end{array}$ & $8(1-53)$ & $4(1-39)$ & 0.332 \\
\hline The number of patients who were applied IVIG, $\mathrm{n},(\%)$ & $13(26 \%)$ & $7(41 \%)$ & 0.628 \\
\hline \multicolumn{4}{|l|}{ Response to IVIG therapy, $n,(\%)$} \\
\hline $\mathrm{CR}$ & $7(53.8 \%)$ & $2(28.5 \%)$ & 0.337 \\
\hline Response & $5(38.5 \%)$ & $5(71.5 \%)$ & \\
\hline No response & $1(7.7 \%)$ & $0(0 \%)$ & \\
\hline $\begin{array}{l}\text { The number of patients who underwent splenectomy, } \mathrm{n} \\
(\%)\end{array}$ & $11(22 \%)$ & $4(23.5 \%)$ & 1.000 \\
\hline \multicolumn{4}{|l|}{ Response to splenectomy, $\mathbf{n},(\%)$} \\
\hline $\mathrm{CR}$ & $7(63.6 \%)$ & $1(25 \%)$ & 0.217 \\
\hline Response & $4(36.4 \%)$ & $3(75 \%)$ & \\
\hline \multicolumn{4}{|l|}{ Loss of response to splenectomy } \\
\hline Yes & $6(61.5 \%)$ & $4(100 \%)$ & 0.231 \\
\hline No & $5(38.5 \%)$ & $0(0 \%)$ & \\
\hline $\begin{array}{l}\text { The number of patients who were applied eltrombopag, } \\
\mathrm{n}(\%)\end{array}$ & $16(32 \%)$ & $8(47 \%)$ & 0.295 \\
\hline \multicolumn{4}{|l|}{ Response to eltrombopag therapy, $n,(\%)$} \\
\hline CR & $8(50 \%)$ & $5(62.5 \%)$ & 0.636 \\
\hline Response & $7(43.8 \%)$ & $2(25 \%)$ & \\
\hline No response & $1(6.2 \%)$ & $1(12.5 \%)$ & \\
\hline \multicolumn{4}{|l|}{ Loss of response to eltrombopag, $n,(\%)$} \\
\hline Present & $3(18.75 \%)$ & $0(0 \%)$ & 0.523 \\
\hline Absent & $12(75 \%)$ & $7(87.5 \%)$ & \\
\hline Missing & $1(6.25 \%)$ & $1(12.5 \%)$ & \\
\hline $\begin{array}{l}\text { Response duration to eltrombopag, months, median } \\
\text { (range) }\end{array}$ & $6(1-31)$ & $13(2-51)$ & 0.361 \\
\hline
\end{tabular}

CR: complete response

\section{Discussion}

In recent years, it has been noticed that the management of hematological diseases such as lymphoma, chronic lymphocytic leukemia, acute myeloid leukemia and myelodysplastic syndrome requires privileged approach in patients with older ages.11-13 However there is not such a distinction in elderly ITP patients, although the management approach to ITP is well defined with guidelines in adult population.4,6,14 But, the world population is aging and the incidence of ITP increases with age; in addition bleeding complications and mortality are more frequent in older ITP patients compared to the young ones.15,16 So, it is indispensable to establish an individualized treatment approach in older ITP patients. Before that, the differences between the old and young ITP patients should be exhibited properly. So, we analyzed the clinical characterisitcs and the treatment outcomes of the young and the old ITP patients and found that both groups were comparable despite the higher rate of comorbidities and medication usage in older patients.
Corticosteroids are the first line therapies for ITP patients who require treatment $[4,6,17]$. Although the initial response rate to CS treatment, varying from 50 to $90 \%$, is acceptable, a sustained response could be ensured in only $10-30 \%$ of patients, after the cessation of CS treatment.5 Similar to the previous studies, we found that the response rate to CS therapy was $86.6 \%$ in our cohort and the results were comparable in patients $\leq$ $60 \mathrm{y}$ and $>60$ y $(86 \%$ v.s. $82.6 \%)$. On the other hand, the loss of response was lower than expected in both young and older ITP patients $(34.1 \%$ v.s. $35.7 \%)$. But the duration of response was median 8 (range, 1-53) months in patients $\leq 60 \mathrm{y}$ and 4 (range, 1-39) months in patients $>60 \mathrm{y}$, either of which was not long enough to advert to the sustained response.

Although, splenectomy is still one of the most common therapeutic approach in refractory ITP patients, in our cohort the number of patients who underwent splenectomy was relatively low, especially in old age, to make a comment about the outcomes of splenectomy.4,6,17 The reason of the low 
number is likely the introduction of thrombopoietin receptor agonists (TPO-RAs) in the treatment of ITP patients, which are a good alternative in old ITP patients with good safety profile and efficacy, considering the presence of comorbidities preventing splenectomy in that group of patients. In recent years, TPO-RAs eltrombopag and romiplastin, which stimulate platelet production in the bone marrow, are used frequently in adult ITP patients at risk of bleeding who relapse after splenectomy or who have contraindications to splenectomy and who have failed at least one other therapy.4,6 In this study, the response and loss of reponse to eltrombopag was alike in young and old ITP patients. Although it did not reach

\section{REFERENCES}

1. Cines DB, McMillan R. Pathogenesis of chronic immune thrombocytopenic purpura. Curr Opin Hematol 2007;14:511-14.

2. Stasi R, Evangelista ML, Stipa E, Buccisano F, Venditti A et al. Idiopathic thrombocytopenic purpura: current concepts in pathophysiology and management. Thromb Haemos 2008;99:4-13.

3. Cines DB, Bussel JB, Liebman HA, Luning Prak ET. The ITP syndrome: pathogenic and clinical diversity. Blood 2009;113:6511-21.

4. Neunert C, Lim W, Crowther M, Cohen A, Solberg L Jr et al. The American Society of Hematology evidence-based practice guideline for immune thrombocytopenia. Blood 2011;117:41904207.

5. Cines DB, Bussel JB. How I treat idiopathic thrombocytopenic purpura (ITP). Blood 2005;1;106:2244-51.

6. Cuker A, Neunert CE. How I treat refractory immune thrombocytopenia. Blood 2016;22;128:1547-54.

7. https://www.who.int/news-room/factsheets/detail/ageing-and-health

8. Wildiers H, Heeren P, Puts M, Topinkova E, Janssen-Heijnen ML et al. International Society of Geriatric Oncology consensus on geriatric assessment in older patients with cancer. $J$ Clin Oncol 2014;20;32:2595-603.

9. McLachlan AJ, Pont LG. Drug metabolism in older people--a key consideration in achieving optimal outcomes with medicines. J Gerontol A Biol Sci Med Sci 2012;67:175-80.

10. https://www.who.int/healthinfo/survey/ageingdefn older/en/

11. Buske C, Hutchings M, Ladetto M, Goede V, Mey $\mathrm{U}$ et al. ESMO Lymphoma Consensus Conference Panel Members. ESMO Consensus Conference on malignant lymphoma: general perspectives and recommendations for the clinical management of a statistical significance, the response duration was longer in old ITP patients.

In conclusion, despite the fraility in old patients due to the comorbidites, the treatment outcomes of old ITP patients seem to be similar to the young ones. But, limitiations such as restrospective nature of the study, relatively low number of old patients and inadequate data about the treatment side effects in this study, prevent to make a definite conclusion about the treatment outcomes between the old and the young ITP patients. The treatment outcomes and side effects of the therapies in old ITP patients should be explored in patients with larger sample size and with more detailed data.

the elderly patient with malignant lymphoma. Ann Oncol 2018;1;29:544-62.

12. Heraly B, Morrison VA. How I treat chronic lymphocytic leukemia in older patients. J Geriatr Oncol 2015;6:333-40.

13. Klepin HD, Rao AV, Pardee TS. Acute myeloid leukemia and myelodysplastic syndromes in older adults. J Clin Oncol 2014;20;32:2541-52.

14. Rodeghiero F, Stasi R, Gernsheimer T, Michel M, Provan D et al. Standardization of terminology, definitions and outcome criteria in immune thrombocytopenic purpura of adults and children: report from an international working group. Blood 2009;12;113:2386-93.

15. Lucchini E, Fanin R, Cooper N, Zaja F. Management of immune thrombocytopenia in elderly patients. Eur J Intern Med 2018;58:70-76.

16. Martinez MCM, Hurst K, Castellano MEM, Mazo AIH. Primary Immune Thrombocytopenia in Elderly Patients: Clinical Profile, Efficacy and Safety of Treatment Protocols. Blood 2014;124:4196.

17. Psaila B, Bussel JB. Refractory immune thrombocytopenic purpura: current strategies for investigation and management. $\mathrm{Br} J$ Haematol 2008;143:16-26. 